\title{
Urgences
}

\section{Quand j'ai pris connaissance...}

\section{André Vanasse}

Numéro 15, octobre 1986

Épigraphiques

URI : https://id.erudit.org/iderudit/025323ar

DOI : https://doi.org/10.7202/025323ar

Aller au sommaire du numéro

Éditeur(s)

Urgences

ISSN

0226-9554 (imprimé)

1927-3924 (numérique)

Découvrir la revue

Citer ce document

Vanasse, A. (1986). Quand j'ai pris connaissance... Urgences, (15), 58-59.

https://doi.org/10.7202/025323ar d'utilisation que vous pouvez consulter en ligne.

https://apropos.erudit.org/fr/usagers/politique-dutilisation/ 


\section{André Vanasse}

"S'ils essaient vraiment de me répondre, il sont finis!"

Jean Larose, dans Georges-Hébert Germain: "Le critique en formule 1" (L'Actualite, septembre 1986)

Quand j'ai pris connaissance de cette menace dans le numero de septembre de L'Actualité, j'ai été catastrophé. Georges-Hébert Germain se faisait catégorique au sujet de Jean Larose, "38 ans, né à Valleyfield, ex-enfant de choeur, docteur ès lettres de l'Université de Vincennes" (p. 140): cet Ivan-le-Terrible du Québec pouvait trucider du rayon laser de son intelligence quiconque voulait se frotter à lui et plus particulièrement les "deux poètes de la NBJ [qui avaient] répondu assez mollement, dans la revue Voix et Images, aux sauvages attaques qu'il avait menées contre eux" (p. 142)?

— "S'ils essaient vraiment de me répondre, ils sont finis!" (p. 142) lançait-il en guise de menace.

Connaissant les pouvoirs mortifères de Jean Larose pour avoir été acidifié au troisième degré le jour où j'avais plongé dans sa prose décapante (précisément cette chronique où il démontrait brillamment l'inanité du numéro de Voix et Images consacré à la BJ/NBJ), je me suis précipité sur le téléphone pour connaître les intentions des deux poètes en question (on me permettra de taire leur nom pour la circonstance). Ceux-ci, à mon grand soulagement, me confièrent que depuis le jour où ils avaient été pulvérisés par celui que G.-H. Germain avait qualifié de "pilote d'élite littéraire" et de "critique en formule 1", ils étaient tous les deux obligés de se ramasser quotidiennement à la petite cuiller. "Nous nous taisons. C'est le mieux que nous puissions faire. Un mot, une parole et nous courons le risque d'être à tout jamais rayés du monde universitaire. Il faut prendre au sérieux cette menace parue dans L'Actualité? Nous vous en supplions, taisez-vous, laissez s'apaiser sa colère".

Bien sâr, j'ai acquiescé. Je n' ai pas osé leur confier quej'avais da quitter, au printemps dernier, la direction de Voix et Images suite à une semonce que m'avais servie le recteur de l'UQAM. Ce dernier ne pouvait comprendre que j'aie ulcéré "celui qu'on dit être le plus brillant, le plus pénétrant de la littérature québécoise, l'intellectuel de haut vol" (p. 141). 
- Comment avez-vous pu commettre un impair pareil? C'est inadmissible. Vous vous rendez compte dans quelle position ridicule vous nous placez, nous tous de l'UQAM? Attirer la colère de Jean Larose, c'était la seule chose à ne pas faire! Saviez-vous, au moins, qu'il avait été enfant de choeur?

- Je l'ignorais, monsieur le recteur.

- Imbécile! 